II presente documento viene fornito attraverso il servizio NILDE dalla Biblioteca fornitrice, nel rispetto della vigente normativa sul Diritto d'Autore (Legge n.633 del 22/4/1941 e successive modifiche e integrazioni) e delle clausole contrattuali in essere con il titolare dei diritti di proprietà intellettuale.

La Biblioteca fornitrice garantisce di aver effettuato copia del presente documento assolvendo direttamente ogni e qualsiasi onere correlato alla realizzazione di detta copia.

La Biblioteca richiedente garantisce che il documento richiesto è destinato ad un suo utente, che ne farà uso esclusivamente personale per scopi di studio o di ricerca, ed è tenuta ad informare adeguatamente i propri utenti circa i limiti di utilizzazione dei documenti forniti mediante il servizio NILDE.

La Biblioteca richiedente è tenuta al rispetto della vigente normativa sul Diritto d'Autore e in particolare, ma non solo, a consegnare al richiedente un'unica copia cartacea del presente documento, distruggendo ogni eventuale copia digitale ricevuta.

Biblioteca richiedente: Università degli Studi di Firenze - Biblioteca di Scienze Sociali

Data richiesta: 30/09/2016 10:38:15

Biblioteca fornitrice: Biblioteca di Ateneo - Divisione Monografie e ILL-DD Università di Trento

Data evasione: $\quad 30 / 09 / 201612: 15: 36$

Titolo rivista/libro: International journal of public administration

Titolo articolo/sezione: The Performance of Nursery Schools in Italian Municipalities

Autore/i:

Gori,Elena;Fissi,Silvia;Manetti,Giacomo

ISSN:

0190-0692

DOI:

Anno:

Volume:

Fascicolo:

Editore:

Pag. iniziale:

Pag. finale: 


\section{The Performance of Nursery Schools in Italian Municipalities}

\section{Elena Gori , Silvia Fissi \& Giacomo Manetti}

To cite this article: Elena Gori , Silvia Fissi \& Giacomo Manetti (2012) The Performance of Nursery Schools in Italian Municipalities, International Journal of Public Administration, 35:14, 959-975, DOI: $10.1080 / 01900692.2012 .696295$

To link to this article: http://dx.doi.org/10.1080/01900692.2012.696295

曲 Published online: 09 Nov 2012.

Submit your article to this journal $[\pi$

Џ Article views: 69

Q View related articles $\square$ 


\title{
The Performance of Nursery Schools in Italian Municipalities
}

\author{
Elena Gori, Silvia Fissi, and Giacomo Manetti \\ Department of Business and Economics, School of Economics, University of Florence, Florence, Italy
}

\begin{abstract}
In a neo-liberal approach, the need to increase levels of cost saving, effectiveness, and quality in producing local public services is correlated to awareness of the limited resources available and is an economic issue that has been much debated in recent decades. Ways of measuring and evaluating public services have stimulated academic interest for several years now. In this context, evaluating the levels of performance of public services provided by non-profit organizations (NPOs) as a consequence of contracting-out by public administration is an essential variable in rationalizing — both in terms of quantity and quality - public expenditure.

The aim of this article is to measure multi-dimensional aspects of nursery school services offered by Italian municipalities and to verify whether using different management models makes a difference in the results obtained. We examine data contained in final accounts of main Italian municipalities in order to evaluate effectiveness, cost saving, and quality aspects of the nursery school service supplied.

Regarding overall performance, the distinction between direct management and contracting-out has not brought out significant differences in terms of effectiveness and cost saving, even if the direct management solution is better than the externalized one. By contrast, as previous research showed, quality levels for externalized services are on average lower than for directly managed services.
\end{abstract}

Keywords: nursery schools performance, Italian municipalities, local public on demand services

\section{INTRODUCTION}

Most European and Western administrative systems were influenced by the wave of reforms in the 1980s and 1990s known under the label of "New Public Management" (NPM) and taking the specific forms of deregulation, privatization, and the introduction of "market" mechanisms within the administration itself (Hood, 1998; Vickers \& Wright, 1988). NPM has been inspired by the ideal of neo-liberalism, understood as a market-driven approach to economic and social policy that supports the higher efficacy of private organizations in providing public services compared with those that are directly provided by public administrations (Clarke,

Although the article is the result of a team effort, Giacomo Manetti can be considered the author of "Introduction," Elena Gori the author of "The Nursery School System in Italy" and of "Theoretical Framework," and Silvia Fissi the author of "Method" and of "The Performance of Nursery Schools in Italy." "Conclusions" has been written by the three authors.

Correspondence should be addressed to Elena Gori, Department of Business and Economics, University of Florence, Via delle Pandette 9, 50127 Florence, Italy. E-mail: elena.gori@unifi.it
2004). Neo-liberalism is in turn influenced by neoclassical theories of economics and consequently it sustains the efficiency of private organizations, and the importance of liberalized markets and trade in stimulating economic growth (Gibson, 2010; Leo \& Enns, 2009). Moreover, "some NPM innovations clearly belong to a neoliberal market paradigm, with its emphasis on market-type mechanisms"-for example, privatization and outsourcing (Morten Balle, 2011).

NPM reforms have led to a redefinition of the relationship between market, society, and the state, where the latter has lost its dominant position that it now has to share with the market. Furthermore, in all countries, even the UK, which had adopted neo-liberalism to the greatest extent during the 1980 s, the state has held its role of strategic planner in a hybrid model where both state interventionism and neo-liberalism co-exist side by side (Loughlin, 2009).

It also necessary to recall that, in a neo-liberal perspective, the need to increase levels of effectiveness and quality in producing local public services is very often correlated to awareness of the limited resources available and to the need to pursue cost savings in a context of growing resource scarcity (Ancarani \& Capaldo, 2001; Cooper, 2003; Kelman, 
2002). To this end, NPM has modified bureaucratic structures and managerial processes in an attempt to improve the productivity, efficiency and performance of the administrative state (Hood, 1991; Lane, 1990; Pollitt \& Bouckaert, 2004).

Part of the literature has been critical of this movement toward the adoption of private sector practices and has stressed the many weak points of such an approach: poor accountability mechanisms, underestimation of public sector values, tendency to reduce political issues to administrative questions, and lowered emphasis on the core administrative values of equity and fairness (Brewer, 2000). Nevertheless, while many theses have been presented against these reforms, NPM researchers have been slow to test the theoretical infrastructure of NPM, verifying whether a more market oriented approach to managing public services leads to better results (Walker et al., 2011).

In the context of NPM, evaluating the levels of performance of public services provided by non-profit organizations (NPOs) as a consequence of contracting-out by public administration is an essential variable in rationalizing - both in terms of quantity and quality-public expenditure. This more frequent use of private suppliers is justified by expenditure, lower costs and/or better quality of services provided, thanks to the experience and professionalism of the NPOs in this field (Amirkhanyan, 2010). However, this supply model, if it is to be more effective and efficient compared with internal provision of the services, must comprise: enough suppliers to stimulate competition, a reasonably developed market, explicit inclusion in contracts of expected results and a system for monitoring and checking performance (Cooper, 2003; Heinrich, 2000, 2002; Savas, 2005).

In the process of contracting-out of public services in the European Union (EU), nursery education plays a central role because of the importance of providing proper childcare, as stressed in the Lisbon Agenda, which defined specific aims for these services (European Commission, 2007).

In the last two decades, management and care of nursery schools, traditionally subject of social and educational analysis, has assumed an increasing importance also in the economic debate. Attention is directed to aspects of regulation that can facilitate the combination of low cost and high quality of services and the implications that the availability of such services can have on citizens' quality of life (Hoffert \&Wissoker, 1992; Heeb \& Kilburn, 2004; Zollino, 2010). In relation to the EU's social goals, Italy belongs to the group of countries that are further behind, even though quality levels of services are higher than the average (Del Boca \& Vuri, 2007).

In light of the above, the main aim of this article is to measure multi-dimensional aspects-effectiveness, cost saving and quality - of nursery school services offered by Italian municipalities, verifying whether using different management models makes a difference to the results obtained. In other terms, we attempt to verify the validity of NPM in the Italian nursery school service as consequence of the introduction of "market" mechanisms within its processes of delivering, management and organization by Italian municipalities in the last two decades. In the international literature, in fact, there are few studies on the efficacy of contracting-out practices with regard to the nursery school service and no evidence regarding Italy, where this kind of service is directly managed by local municipalities. The Italian perspective is particularly missing, which we consider a blatant deficit of research in NPM.

Against this background the particular contribution of this article to the scholarly discussion is to enhance empirical knowledge on local NPM-reform impacts in Italy with particular reference to the nursery school service. In doing so, we hope to fill up —at least to some extent- the research gap that has existed so far in this field. We will therefore structure our research on the above-mentioned multi-dimensional aspects of Italian municipalities in three main areas of interest, using a set of indicators to determine the levels of:

1. effectiveness (observed particularly as the ability to satisfy requests);

2. cost saving (studied particularly as the cost per head);

3. quality of service (observed particularly as the ability to limit the number of children attending per operator and, in particular, per educator).

Finally, we will verify the existence of a statistical correlation between the principal indicators, by identifying them among those calculated for the three aspects studied.

In light of the above premises, aim of this article is to measure, using the already mentioned measures, the levels of effectiveness, quality, and cost savings of nursery school services offered by Italian municipalities and to verify whether using different management models makes a difference to the results obtained.

In the following sections we will continue to:

- explain the Italian political commitment to development of nursery school services and properly define the theoretical framework for supporting the role of market in providing public services and especially human services contracted-out to NPOs;

- explain the choice of the proposed indicators for measuring the effectiveness, the quality and levels of cost savings of nursery school services;

- describe the results of an empirical survey on nursery school services of the Italian municipalities applying the chosen indicators to internally managed services and to contracted-out services;

- reach a conclusion as to the role that outsourcing and contracting-out assume in the provision of nursery school services in Italy. 


\section{THE NURSERY SCHOOL SYSTEM IN ITALY}

The European Council has decreed that all member states must provide childcare for at least 90 percent of children between three and six years and at least 33 percent of those under three years of age (European Council, 2005). Childcare distribution varies considerably from country to country, but the majority is still below the target established by the Lisbon Agenda. Denmark, Sweden, and Ireland, in particular, have high distribution of early childcare, covering 40 percent of children under three. Finland, the Netherlands and France are covered for 30 percent, while much lower percentages are found in Germany (10 percent), the Czech Republic ( 3 percent), and Poland ( 2 percent) (European Commission, 2008a).

In Italy, attention to nursery schools is relatively recent. The first regulations concerning childcare are found in Law 1044/1971 "Five-year plan for establishing municipal nursery schools with government support." This defined nursery schools, for the first time, as a social service in the public interest, which might facilitate women's entry into the job market. On this point, it is interesting that in Italy, 40 years on, the motivation underlying the growth of nursery schools is still the same: to safeguard and encourage female occupation (Ministry for Public Administration and Innovation, 2010, p. 4). This objective was a key feature of the 2002 and 2003 Financial Acts, which earmarked funds for creating nursery schools in public and private workplaces. However, a modification made to Part V of the Constitution and the resulting change of competency in this matter, together with Supreme Court rulings nos. $370 / 2003$ and $320 / 2004$ that determined the impossibility of using government funds, decreeing that nursery schools, as a public service, were the responsibility of Regions and local authorities, meant that the funding process could not be put into practice.

Subsequently the 2007 Financial Act (L. 296/2006, paras. 1259-1260) included a special action plan to develop a territorial system of educational and social services, in order to reach the common European objective of 33 percent coverage for childcare services as decided in the Lisbon Agenda. This funding was increased in the 2008 Financial Act (L. 244/2007, comma 457). Altogether, the Special Plan set aside for 2007-2009 446 million Euro in public funds, to increase places available for children from 0 to 3 years of age. To this was added local co-financing of about 281 million Euro, for a total of 727 million Euro. Overall, the Plan's funds should have created an additional 65,000 places, although this would not in any case have met the objective of 33 percent (Council of Ministers Presidency, 2009). Finally, the government through the Ministry for Equal Opportunity has decided on a series of actions to help to reconcile work and family life, allocating resources to additional services within the family and in homes, setting up so-called "family nurseries" or "childminders." Based on national legislation, each Italian Region then legislated nursery school services with regulations for the organization, and funding and governance of educational and social services for infants.

Currently, in Italy, the percentage of cover for children under three is 6 percent if only public services are considered and 26 percent if private structures are included. But about 358,000 places are needed to reach the objective of 33 percent (European Commission, 2008a; Toto, 2010). However, the EU target only takes into account the quantitative aspect while, according to an enquiry carried out across Europe by UNICEF and ChildONEurope, the majority of nations surveyed also feel that uniform quality standards are necessary (UNICEF, 2008). In evaluating nursery schools, quality elements held to be particularly fundamental are the space available for children, the child-educator ratio, and, above all, the cost-quality ratio (NESSE, 2009). The same conclusions were also reached by a subsequent enquiry, which stated the need to establish a definition of quality common to member states (Bernacchi, 2010). Recent studies have found that innovation and the economic and quality aspects of managing nursery services are often a focus of interest for politics and public opinion (Council of Ministers Presidency, 2009).

An important part of the debate on the running of nursery schools is the need to move towards privatization or outsourcing of services, in order to improve levels of cost saving, effectiveness, and quality (Department for Families, 2007).

\section{THEORETICAL FRAMEWORK}

Considerable changes have taken place in the running of local public services at global and European levels (Pollitt \& Geert, 2000; Torres \& Pina, 2002). These changes are strictly connected to the NPM movement which started a process of transferring the logic, principles and management techniques used in private firms into public organizations. An adaptation of private organizational models, rather than a direct copying of them is required (Bozeman, 1987; Ferlie et al., 2005). According to Hood (1991), Kettel (2005) and Trotta et al. (2011), NPM represents a paradigmatic break from the traditional model of public administration, and suggests the following changes: privatization, emphasis on the citizen as client, strategic management, measuring results and evaluating performance, the use of the market mechanism (in particular contracting-out), downsizing, and the separation of politics and administration. In other words, "NPM aims to increase efficiency and effectiveness in order to reduce costs and to improve performance" (Trotta et al., 2011).

Nevertheless, there are notable difficulties in measuring and evaluating public service performance especially if services are delivered on demand. Public performance is highly multi-dimensional due to the coexistence of political and business variables and to objectives that may 
be mutually contrasting (Boaz \& Nutley, 2003; Bovaird \& Loeffler, 2003; Rainey, 1989). Moreover, the evaluation of local public service performance is strictly linked to how services are run. Increasingly, hybrid forms are common (partnerships, collaborations, networks, externalizations, or alliances) (Angroff \& McGuire, 2003; Gulati et al., 2000). If we consider this aspect, NPM is critical about monopolistic forms of service provision and requires a wider range of service providers and more market-oriented approach to management (Stoker, 2006). This is also a consequence of the application of neo-liberal values (Hansen \& Lauridsen, 2004).

The concept of performance, or rather of public value, must consider the service's contribution to obtaining positive economic results and to satisfying public needs (Lewis \& Pattinasarany, 2009). As previously noted, public service performance evaluation cannot be limited to some aspects only, but must consider all variables connected with its effectiveness, cost saving, and quality. Public/private partnership agreements are based on the objective of rationalizing the scarce resources available and obtaining higher performance levels (Warner \& Germa, 2008). The debate on privatization of public services, therefore, is one of the key issues for public administration nowadays, considering the fact that users expect high quality services at the lowest possible rates (Leland \& Smirnova, 2009).

Another particularly interesting aspect studied by experts concerns the problems connected with public service externalization (Barlow\& Rober, 1996; Ferris\& Graddy, 1991; Osborne \& Gabler, 1992; Savas, 2000). Outsourcing and contracting-out, in fact, have not always led to improvements in cost saving, effectiveness and quality (Grossi \& Mussari, 2008). In the public domain, contrasting results have often been found regarding the efficiency and effectiveness of externalization. On the one hand, high levels of cost saving can be reached, but on the other, it is generally held that externalized services are of inferior quality (Boyne, 1998; Gruening, 2001; Reichard, 2002).

On this subject, results of empirical research show that there is often a direct connection between how public services are run and the economic results, efficiency and quality obtained (Andrews\& Entwistle, 2010). In particular, there is a direct positive correlation between the production and supply of on demand public services by public bodies and levels of effectiveness, cost saving and quality (Bryson et al., 2006; Warner \& Germa, 2008). On the contrary, where there is a public/private partnership producing the service, there is a direct negative correlation in the service's levels of effectiveness and efficiency (Bloomfield, 2006; Lasker et al., 2001).

Compared to the private sector, the evaluation of performance in the public sector is relatively complicated: public accounts are very different from the private ones making it difficult to obtain information on costs at a disaggregated level (Mihaiu et al., 2010) and public budgets are not really designed to track down specific sector expenditures
(Estache et al., 2007). The measurement of public service performance remains a conceptual challenge as public spending has multiple objectives (Mandl et al., 2008).

In light of the above, in following sections we briefly describe the concepts of effectiveness, cost savings and quality of service that we want to measure through our empirical analysis of nursery school services offered by Italian municipalities, aiming to verify whether using different management models makes a difference to the results obtained.

\section{Effectiveness}

The analysis of effectiveness, together with efficiency, considers the relationship between inputs, outputs and outcome (Farrell, 1957). Effectiveness relates the input or the output to the final objectives (outcome) and it shows the success of the resources used in achieving them. The efficiency is related to the input-output ratio, but efficiency and effectiveness are not always easy to isolate and they are both affected by environment factors (Afonso et al., 2005). To evaluate the performance, it is essential to distinguish between inputs, outputs and outcomes. Inputs are the resources allocated to services and they can be estimated in monetary and non-monetary (physical) terms. In this article we consider public spending allocated to the production of a given public service as a measure of input to evaluate the service's cost saving capacity. An additional approach to defining appropriate input indicators is to use non-monetary factors, like the teacher/student ratio or class size, to measure inputs.

Outputs are the activities local governments undertake, such as the provision of services (Schacter, 2002). Outcomes are the results of those activities in terms of the common good (Curristine et al., 2007). In this sense, service effectiveness is strictly connected to activities (i.e., the provision of a service) and the outcomes (i.e., the satisfied requests) (Bird et al., 2005). The effectiveness of service is correlated to its capacity to respond to user needs, considering the ratios between potential users, requests received, and requests satisfied (Boyne, 2002). If we consider effectiveness as the organization's capacity to satisfy citizens' requests, we probably will find differences between services directly provided by local authorities and those run with a hybrid form in a last attempt to maximize profit on investment, by maximizing the number of clients (Amirkhanyan, 2010; Mihaiu, et al., 2010).

\section{H1: Nursery schools with externalized services will have higher levels of effectiveness than those managing services themselves.}

\section{Cost Saving}

The most basic measure of efficiency is the input-output ratio, but the efficiency concept incorporates also the idea 
of the production possibility frontier, which indicates feasible output levels: at a given input, the greater the output or at a given output, the lower the input is, the more efficient the activity (Afonso et al., 2006). The fact that outputs in the public sectors are amorphous and intangible in many respects makes it difficult to define a supply function in a traditional sense, while the fact that public sector organizations produce goods that are free at the point of use means that prices of outputs are not determined by market forces (OECD, 2007b, p. 264). It follows that economic efficiency cannot be directly measured; therefore, different approaches concerning data and methodological framework have been used (Afonso \& Aubin, 2005; Mandl et al., 2008; Tanzi \& Schuknecht, 2000). In general, these authors measure efficiency in public services by using composite indicators (OECD, 2007a). Unfortunately the problem with such composite indicators is the subjectivity involved in choosing them and the difficulty of attributing a correct weight for each sub-indicator (Mandl et al., 2008).

However, understanding the cost of services and their outcomes in monetary terms is crucial to conducting business. According to the Great Britain Audit Commission, efficiency in the public sector can be interpreted as its capacity in cost saving and it can be measured by information regarding the economic sustainability of on demand local public services including unit cost, unit revenue, and the service's degree of cover (Audit Commission, 2001). The financial sustainability of nursery schools differs greatly from one EU member state to another. Also, as the Commission notes, the cost can vary significantly even within the same country depending upon the type of service, whether public or private and the taking into account of parents' income level (European Commission, 2008b; European Commission, 2008c, p. 7).

If we consider the cost saving aspect together with contracting-out, many authors underline that outsourcing or privatizing public services lead to higher levels of cost saving (Hilke, 1993). These results were explained by some factors such as better management techniques, better and more productive equipment, greater incentives to innovate, incentive pay structures, more efficient deployment of workers, greater use of part time and temporary employees, utilization of comparative-cost information, and more work scheduled for off-peak hours.

H2: Nursery schools with externalized services will have higher levels of cost saving than those managing services themselves.

\section{Quality of Service}

Many scholars, especially those belonging to schools of thought inspired by neo-liberalism, believe that a quality public service must have three characteristics: it must be useful, and effective in pursuing public ends and, lastly, economically sustainable (Van Der Steen, 1996). A public service of adequate quality must therefore respect customer expectations in terms of usefulness and effectiveness, but must also be the output of an efficient and economically sustainable process (Boland \& Flower, 2000; Curry \& Herbert, 1998; Erridge et al., 1998; Sanderson, 1996).

Moreover, to mitigate subjectivity in evaluations owing to the presence of stakeholders with opposing interests, official data that are uniform for all local authorities should be used when formulating indicators (Boyne, 2003; Frederickson \& Frederickson, 2006). Qualitative aspects can be evaluated using elements from how the service is organized such as, for example, average size of structure and the ratio of operators, divided by qualification, to users (Fraumeni et al., 2004; UNICEF, 2008). In other words, it is possible to evaluate service quality by using structural indicators referring to the relatively stable characteristics of the service, the tools, and the resources used (Malley \& Fernandez, 2010).

The European Commission also agrees that quality of service is a decisive aspect of nursery school performance evaluation (European Commission, 2008c). In particular, important aspects are the type of service offered, quality regulations, and the number and training of operators. Another fundamental element, in the Commission's opinion, when evaluating quality of service is the ratio between number of educators and children. This, however, varies considerably among member states, from 1:3 up to 1:7, while the requirement to respect these coefficients depends on the laws of each member state.

From a qualitative point of view, in the majority of European countries, including Italy, there is a strong focus on setting minimum quality standards for structures with reference to opening hours, class composition by number and age of children, minimum space for green and covered areas, and the number of teachers per class and their levels of qualification (Plantenga et al., 2008). Unfortunately, for externalized nursery schools recently reported facts demonstrate that local authority control is not sufficiently strict to avoid poor quality services, even where fixed quality standards for nursery schools exist.

Referring to service quality, authors opinions; vary : the majority believes that externalized services have inferior quality compared to directly managed ones since private organizations try to save costs, even by reducing the quality of services, to get high profits (Forrer et al., 2010; Gollust \& Jacobson, 2006; Hoppe \& Schmitz, 2011; Siemiatycki, 2011). Others argue that in some cases the externalized services quality is better as the organizations are less bureaucratic and more flexible than the public ones (Bel \& Warner, 2008; Mercer, 1983; Savas, 2000, p. 147).

H3: Nursery schools with externalized services will have lower levels of quality than those managing services themselves. 


\section{METHOD}

The unit of investigation is the Italian municipality. Their vast number - 8,101 with 56,995,744 inhabitants at the last general population census in 2001 - would call for a statistical sample to be constructed. But, since research focuses on nursery school services, it is important to be sure that they are effectively provided by the bodies surveyed.

To date, numerous studies have been made into nursery school services provided by Italian municipalities. Yet often these were ministerial investigations whose aim was to evaluate the impact of family support policies or to suggest possible future strategies (Ministry for Public Administration and Innovation, 2010; Ministry for Equal Opportunities, 2007). Rarely was the aim to evaluate costs borne by Italian municipalities in providing these services. Moreover, these investigations illustrate case studies where the service is provided in different ways. Their very nature does not allow them to give an overall view of the phenomenon (Landriani \& D'Amore, 2009).

Nursery school services are provided above all by the larger municipalities, primarily in those with over 50,000 inhabitants. Here the percentage of coverage frequently reaches 100 percent, apart from in Southern Italy where, in 2007, it stopped at around 33 percent (Gori \& Fissi, 2010; Istat, 2010). We have therefore decided to limit our analysis to the larger municipalities and have concentrated on the populations of the capitals of the 107 provinces existing in 2006 (corresponding to 1.32 percent of Italian local municipalities and to 35.79 percent of larger municipalities-more than 30,000 inhabitants). Already by 2005 , in fact, 45 percent of municipal nurseries and 51 percent of places available were concentrated in the capitals of the Italian provinces (Toto, 2010, p. 8).

Having established the population of the municipalities to be analyzed, we took the following steps:

- Firstly, we collected data on the "nursery school" service, analyzing section 14 on local public services on demand for the last available final accounts - 2008 on the Ministry of Interior website. Though these data are minimal, it is nonetheless very interesting as it is common and uniform throughout the whole of Italy. Specific systems of monitoring and control, on the other hand, are not widespread and, being set up according to the particular requirements of each municipality, would not provide consistent data, so would be difficult to compare (Ministry for Public Administration and Innovation, 2010).

- Secondly, data contained in final accounts have been recorded by distinguishing municipalities according to the type of management used for providing the services in question. ${ }^{1}$ In fact, an element considered by the authors in evaluating local public services is linked to the type of control: there is a significant difference between internal services - easier to monitor - and external ones (Brown et al., 2006). Internal services are managed directly by the local authority employing its own personnel, while external or contracted-out services are managed by private entities through their employees, on the basis of separate agreements with the local authority. The majority of municipalities chose direct management (code 1), we separated those who used this form of management from the others, thus forming two groups. For the second group, made up of municipalities who do not directly manage their nursery school services, we had to identify the specific form of management used.

The next step was to construct indicators to evaluate management of the service in both groups of municipalities. As mentioned in the literature, the development of a successful methodology for measuring the public services' performance requires an alignment among key factors such as effectiveness, cost saving, and quality of services (Schacter, 2002). In general, performance indicators are the measure used to assess a specific aspect of performance and that no single indicator is adequate (Wholey \& Hatry, 1992). It is therefore advisable to adopt a set of basic indicators that are able to monitor the three fundamental aspects in evaluating local public services: effectiveness, cost saving, and quality (Audit Commission, 2003; Boyne et al., 2006; Commission for Health Improvement, 2003). These indicators were obviously constructed using data available from the final accounts. So, many others of undoubted interest were not calculated. Where possible, however, indicators chosen were those commonly accepted by legislators and academics. Because this service has a high social value, its economic viability must be evaluated taking into account levels of effectiveness and quality. In fact only by evaluating these three aspects together can we make an overall judgment on how the service is run.

First of all, as far as effectiveness is concerned, we measured the service offered in relation to potential users (the population between 0 and 2 years old), as a ratio between nursery places available and the entire population 0 to 2 years of age. Then, local authorities' responsiveness regarding the service was measured, calculating requests made against

\footnotetext{
${ }^{1}$ Specifically, in Italy, the following forms of management can be used for local public services: code 1: directly managed service; code 2 : service run by municipal business company; code 3 : service run by provincial business; code 4: service run by joint venture; code 5 : service outsourced to consortium; code 6: service outsourced to private and public business; code 7: service run by joint venture, main joint venture; code 8 : service run by joint venture, associated joint venture body; code 9: service with other type of management.
} 
potential users. Lastly, local authorities' response to community needs was measured by calculating the ratio between requests satisfied and those received.

The cost saving was evaluated by finding the cost per head and revenue per head for each child registered and then, by calculating the percentage of service cover as a ratio between total revenue and total cost. These elements allow evaluation of economic sustainability and, above all, of the local authority's choice as to how the service is funded. In fact, a high percentage of cost cover indicates that the authority decided to fund the service directly from user resources, without significantly burdening the community (Ostroff \& Schmitt, 1993).

As far as quality aspects are concerned, we calculated the ratio between available places and number of nurseries, thus estimating the average size. Finally, we found the number of children attending for each operator and, in particular, for each educator. Local authority awareness regarding the service can be judged by calculating the ratio of available places to potential users, while the degree of use made of the service is illustrated by the ratio between potential users and requests received. The ratio of requests satisfied to those received permits evaluation of the authority's response to a community need.

Finally, we verified the existence of a statistical correlation between the principal indicators, by identifying them among those calculated for the three aspects studied. Indicators which are more significant than others are, for effectiveness, the ratio of requests received to those satisfied, for economic viability, the cost per head and, lastly, for quality, the average size of the nursery. The correlation was measured using Pearson's correlation coefficient (Levine et al., 2002, pp. 422-423).

\section{THE PERFORMANCE OF NURSERY SCHOOLS IN ITALY}

First of all, data concerning nursery school services found in final accounts were elaborated upon. Despite the legal obligation to provide this information, some municipalities did not do so - 6 out of 111 (5.41 percent) - and were eliminated from the sample analyzed. Other accounts were incomplete and could not therefore be used for our research: 20 - corresponding to 18.02 percent of the total - were eliminated. The population to be analyzed was thus reduced to that of 85 units.

Next, we created two groups, the first made up of municipalities who managed the service directly and the second of those who used other methods. Of the municipalities investigated, 79.07 percent run the service directly. The second, less numerous group comprised 18 municipalities, most of whom (15 of them) indicated under type of management of service code 9 "Service with other type of management." Table 1 identifies, for each municipality in this second group, the specific type of management of nurseries. Information was found on the websites of each municipality.

Table 1 shows that the majority of municipalities adopt a hybrid type of management with some structures directly managed and others externalized, using special agreements or run by cooperatives. Three municipalities have handed over management of the service to consortiums and only one has set up a municipal business. In the municipality of Bolzano the nursery school service is run by a municipal business. The final accounts, apart from indicating this type of management, contain no further information. However, given the unusual nature of this choice by the municipality, we thought it interesting to include it in the table, although lack of information prevents us from analyzing the performance achieved.

At this point we calculated the indicators showing the levels of cost saving, effectiveness, and quality for both groups.

Table 2 shows indicators of effectiveness registered for nursery services directly run by the municipalities analyzed, while Table 3 shows results achieved using other types of management. In Table 2, main municipalities of provinces are shown in descending order of performance with respect to the ratio of requests satisfied to those received. Here we observe that only 5 municipalities - Frosinone, Alessandria, Sondrio, Imperia, and Enna - out of 68 (7.35 percent) totally satisfied demand and 12 (17.65 percent) were above average. This means that the majority of authorities analyzed were unable to satisfy demand for the service completely.

Generally, there were insufficient places with respect to potential users. The average is 22.37 percent but numerous municipalities (85.29 percent) were under this threshold a clear sign of high variability. Similar observations might be made for the final indicator of effectiveness - the ratio between requests received and potential users, representing community awareness of the service. Here too, many municipalities register results below average (61.76 percent).

In municipalities where community awareness of the service is high, like Bologna, Pisa, and Pavia, there is a correspondingly good response from the local authority in terms of places available. By contrast, low awareness corresponds to a similarly reduced response in terms of the ratio of places available to potential users (Lecco, Avellino, Foggia, Latina and Crotone). Performance in terms of effectiveness probably also depends on the single territories. In fact, only three out of 12 local authorities in Southern Italy were above average. This phenomenon deserves further investigation.

Table 3 classifies municipalities who outsource management of nursery school services, by percentage of requests satisfied. There are three authorities (17.65 percent) that manage to respond positively to the demand for nursery school places, while 64.71 percent register a result above average, which is, in any case, decidedly lower than that for directly managed nurseries, equal to 85.04 percent. The average degree of awareness about the service both in 
TABLE 1

Type of management used by municipalities that do not directly manage nursery school services

\begin{tabular}{llllll}
\hline $\begin{array}{l}\text { Main municipality } \\
\text { of province }\end{array}$ & \multicolumn{1}{c}{ Province } & \multicolumn{1}{c}{ Region } & Code & $\begin{array}{c}\text { N. of nursery } \\
\text { schools }\end{array}$ & \multicolumn{1}{c}{ Nursery schools' description } \\
\hline Torino & Torino & Piemonte & 9 & 75 & 40 municipal organizations; 35 approved \\
Cuneo & Cuneo & Piemonte & 9 & 3 & 1 municipal organization; 2 approved \\
Aosta & Aosta & Valle d'Aosta & 9 & 4 & 4 cooperatives \\
Bergamo & Bergamo & Lombardia & 9 & 13 & 3 cooperatives \\
Brescia & Brescia & Lombardia & 9 & 18 & 13 municipal organizations; 5 approved \\
Bolzano-Bozen & Bolzano-Bozen & Trentino Alto Adige & 2 & N.P. & Municipal business \\
Trieste & Trieste & Friuli-Venezia Giulia & 9 & 18 & 17 municipal organizations; 1 approved \\
Savona & Savona & Liguria & 9 & 6 & 5 municipal organizations; 1 approved \\
Parma & Parma & Emilia-Romagna & 9 & 39 & 39 approved private organizations \\
Modena & Modena & Emilia-Romagna & 9 & 44 & 20 municipal organizations; 24 approved \\
Ravenna & Ravenna & Emilia-Romagna & 9 & 20 & 11 municipal organizations; 9 in outsourcing \\
Lucca & Lucca & Toscana & 9 & 5 & 3 municipal organizations; 2 approved \\
Rieti & Rieti & Lazio & 9 & 2 & 2 in outsourcing \\
Siracusa & Siracusa & Sicilia & 5 & 7 & Outsourced to consortium \\
Sassari & Sassari & Sardegna & 9 & 7 & 7 cooperatives \\
Tempio Pausania & Olbia-Tempio & Sardegna & 9 & 1 & 1 in outsourcing \\
Lanusei & Ogliastra & Sardegna & 9 & 1 & 1 in outsourcing \\
Villacidro & Medio Campidano & Sardegna & 5 & 1 & Outsourced to consortium \\
\hline
\end{tabular}

Source: Created by the authors.

local authorities and their communities is very low being, respectively, 3.33 percent and 4.41 percent. Of the single authorities, only the municipality of Parma is above the threshold of 35 percent, while others are concentrated in the $10-20$ percent range.

Therefore, the results do not support HI - according to which nursery schools with externalized services should have higher levels of effectiveness than those managing services themselves - since we did not find significant differences between the two diverse systems of service management. Table 4 shows indicators of cost saving registered for nursery services directly run by the municipalities analyzed, while Table 5 shows results achieved using other types of management.

Table 4 classifies municipalities on the basis of results obtained in terms of cost per head of the service. The better performance is clearly that of authorities with lower costs than others, so in this case they are in ascending order. Firstly, we observe high variability and, in general, lower costs per head in authorities in the south. Crotone and Cosenza, occupying the first two places, have particularly positive results. Then the cost rises rapidly, so much so that it has already quadrupled by the tenth position, held by Latina.

Sometimes, municipalities with a low cost per head at the same time show incredibly low revenue per head. In fact it is necessary to consider at the same time the unit cost ratio to degree of coverage. The former is a coefficient of cost saving while the latter is the result of the authority's political decision, i.e., where coverage is high, to charge the cost of the service to the community. In the case of modest cost saving and high coverage, the inefficiencies of the service affect users directly and they are obliged to take the financial strain (Lecco and Asti). In general, the degree of coverage is very low and is total only in the municipalities of Macerata (1.352) and Viterbo (1.006), while it is practically nil in Agrigento (0.008).

Table 5 classifies municipalities in ascending order according to registered cost per head. The average cost per head $(8,162.83$ Euro $)$ is higher than that of directly managed nurseries (7,516.02 Euro). On the other hand, revenue per head for "other forms of management" $(1,407.02)$ is also higher compared with code 1 (1,332.65), so the average cover is similar. Therefore, the results do not support $\mathrm{H2}$ according to which nursery schools with externalized services have higher levels of cost saving than those managing services themselves - since we did not find significant differences between the two diverse systems of service management.

Table 6 shows indicators of quality registered for nursery services directly run by the municipalities analyzed, while Table 7 shows results achieved using other types of management. Table 6 shows the municipalities classified according to size of structure. Smaller nurseries are, as mentioned, qualitatively better structures, so data are shown in descending order. Municipalities having structures below average for the population comprise 54.51 percent of the total.

There is no unitary recommendation, at the European or national level, for the average dimensions of structures only indications as to the educator: child ratio (European Commission, 2008a, p. 10). In Italy regional laws intervene, albeit in a variety of ways, to determine capacity per type of service (National Family Conference, 2010, pp. 28-30). Regarding the number of children entrusted to each member 
TABLE 2

Performance in terms of effectiveness by municipalities that directly manage nursery school services

\begin{tabular}{|c|c|c|c|c|}
\hline \multirow[b]{2}{*}{$N}$. & \multirow{2}{*}{$\begin{array}{c}\text { Main municipality } \\
\text { of province }\end{array}$} & \multirow{2}{*}{$\frac{\text { Satisfied requests }}{\text { Received requests }}$} & \multirow{2}{*}{$\frac{\text { Available positions }}{\text { Potential users }}$} & \multirow{2}{*}{$\frac{\text { Received request }}{\text { Potential users }}$} \\
\hline & & & & \\
\hline 1 & Frosinone & $115.19 \%$ & $12.91 \%$ & $12.91 \%$ \\
\hline 2 & Alessandria & $100.00 \%$ & $14.37 \%$ & $14.37 \%$ \\
\hline 3 & Sondrio & $100.00 \%$ & $12.95 \%$ & $12.95 \%$ \\
\hline 4 & Imperia & $100.00 \%$ & $14.30 \%$ & $15.07 \%$ \\
\hline 5 & Enna & $100.00 \%$ & $12.74 \%$ & $9.55 \%$ \\
\hline 6 & Milano & $98.04 \%$ & $25.20 \%$ & $18.29 \%$ \\
\hline 7 & Asti & $96.11 \%$ & $15.85 \%$ & $18.64 \%$ \\
\hline 8 & Cagliari & $95.43 \%$ & $18.04 \%$ & $22.33 \%$ \\
\hline 9 & Novara & $94.79 \%$ & $21.88 \%$ & $23.08 \%$ \\
\hline 10 & Vercelli & $92.58 \%$ & $14.07 \%$ & $20.65 \%$ \\
\hline 11 & La Spezia & $92.15 \%$ & $19.89 \%$ & $25.85 \%$ \\
\hline \multirow[t]{2}{*}{12} & Campobasso & $90.82 \%$ & $10.47 \%$ & $8.55 \%$ \\
\hline & Average & $85.04 \%$ & $22.37 \%$ & $22.18 \%$ \\
\hline 13 & Carbonia & $86.15 \%$ & $10.00 \%$ & $11.61 \%$ \\
\hline 14 & Viterbo & $83.77 \%$ & $18.58 \%$ & $16.69 \%$ \\
\hline 15 & Bologna & $83.60 \%$ & $36.84 \%$ & $44.07 \%$ \\
\hline 16 & Verbania & $82.35 \%$ & $20.76 \%$ & $31.00 \%$ \\
\hline 17 & Siena & $81.42 \%$ & $28.38 \%$ & $44.13 \%$ \\
\hline 18 & Lecco & $80.20 \%$ & $9.35 \%$ & $7.87 \%$ \\
\hline 19 & Pisa & $79.73 \%$ & $31.01 \%$ & $38.89 \%$ \\
\hline 20 & Forlì & $78.43 \%$ & $24.26 \%$ & $30.93 \%$ \\
\hline 21 & Trento & $76.98 \%$ & $27.44 \%$ & $20.70 \%$ \\
\hline 22 & Teramo & $76.14 \%$ & $19.33 \%$ & $29.60 \%$ \\
\hline 23 & Biella & $75.76 \%$ & $22.34 \%$ & $29.49 \%$ \\
\hline 24 & Catania & $74.37 \%$ & $7.18 \%$ & $12.76 \%$ \\
\hline 25 & Pistoia & $74.30 \%$ & $20.73 \%$ & $27.89 \%$ \\
\hline 26 & Venezia & $72.78 \%$ & $18.70 \%$ & $20.85 \%$ \\
\hline 27 & Pavia & $72.21 \%$ & $25.46 \%$ & $37.20 \%$ \\
\hline 28 & Latina & $71.12 \%$ & $6.67 \%$ & $9.70 \%$ \\
\hline 29 & Como & $70.60 \%$ & $23.13 \%$ & $19.67 \%$ \\
\hline 30 & Firenze & $69.84 \%$ & $31.41 \%$ & $26.94 \%$ \\
\hline 31 & Pesaro & $68.68 \%$ & $22.24 \%$ & $31.71 \%$ \\
\hline 32 & Chieti & $68.57 \%$ & $11.74 \%$ & $17.11 \%$ \\
\hline 33 & Roma & $67.15 \%$ & $15.06 \%$ & $23.20 \%$ \\
\hline 34 & Perugia & $67.02 \%$ & $14.68 \%$ & $26.09 \%$ \\
\hline 35 & Terni & $65.83 \%$ & $7.70 \%$ & $11.70 \%$ \\
\hline 36 & Pordenone & $64.00 \%$ & $6.74 \%$ & $22.34 \%$ \\
\hline 37 & Cremona & $63.22 \%$ & $15.28 \%$ & $10.64 \%$ \\
\hline 38 & Avellino & $63.16 \%$ & $3.56 \%$ & $5.63 \%$ \\
\hline 39 & Napoli & $63.15 \%$ & $4.54 \%$ & $8.90 \%$ \\
\hline 40 & Rovigo & $62.84 \%$ & $10.20 \%$ & $15.05 \%$ \\
\hline 41 & Vicenza & $62.69 \%$ & $21.11 \%$ & $18.44 \%$ \\
\hline 42 & Agrigento & $62.11 \%$ & $6.39 \%$ & $10.29 \%$ \\
\hline 43 & Arezzo & $61.87 \%$ & $18.14 \%$ & $27.90 \%$ \\
\hline 44 & Varese & $61.15 \%$ & $15.82 \%$ & $25.12 \%$ \\
\hline 45 & Mantova & $59.79 \%$ & $18.34 \%$ & $15.98 \%$ \\
\hline 46 & Pescara & $58.99 \%$ & $6.65 \%$ & $11.27 \%$ \\
\hline 47 & Livorno & $58.32 \%$ & $21.02 \%$ & $36.04 \%$ \\
\hline 48 & Verona & $58.29 \%$ & $18.88 \%$ & $18.03 \%$ \\
\hline 49 & Rimini & $58.15 \%$ & $13.71 \%$ & $31.14 \%$ \\
\hline 50 & Ascoli Piceno & $56.85 \%$ & $12.09 \%$ & $13.27 \%$ \\
\hline 51 & Lodi & $55.06 \%$ & $12.08 \%$ & $14.25 \%$ \\
\hline 52 & Foggia & $55.00 \%$ & $1.35 \%$ & $2.26 \%$ \\
\hline 53 & Ancona & $53.89 \%$ & $20.38 \%$ & $21.48 \%$ \\
\hline 54 & Massa & $53.79 \%$ & $12.08 \%$ & $22.46 \%$ \\
\hline 55 & Cosenza & $53.13 \%$ & $5.88 \%$ & $11.07 \%$ \\
\hline 56 & Udine & $52.65 \%$ & $11.49 \%$ & $21.68 \%$ \\
\hline
\end{tabular}


TABLE 2

(Continued)

\begin{tabular}{|c|c|c|c|c|}
\hline \multirow[b]{2}{*}{$N}$. & \multirow{2}{*}{$\begin{array}{l}\text { Main municipality } \\
\text { of province }\end{array}$} & \multirow{2}{*}{$\frac{\text { Satisfied requests }}{\text { Received requests }}$} & \multirow{2}{*}{$\frac{\text { Available positions }}{\text { Potential users }}$} & \multirow{2}{*}{$\frac{\text { Received requests }}{\text { Potential users }}$} \\
\hline & & & & \\
\hline 57 & Piacenza & $52.03 \%$ & $26.89 \%$ & $26.04 \%$ \\
\hline 58 & Padova & $51.32 \%$ & $13.91 \%$ & $13.14 \%$ \\
\hline 59 & Prato & $47.34 \%$ & $8.61 \%$ & $18.19 \%$ \\
\hline 60 & Genova & $46.88 \%$ & $10.39 \%$ & $11.34 \%$ \\
\hline 61 & Salerno & $44.47 \%$ & $6.01 \%$ & $13.51 \%$ \\
\hline 62 & Crotone & $40.00 \%$ & $1.64 \%$ & $4.11 \%$ \\
\hline 63 & Trapani & $39.48 \%$ & $10.48 \%$ & $26.54 \%$ \\
\hline 64 & Ragusa & $36.22 \%$ & $7.67 \%$ & $19.36 \%$ \\
\hline 65 & Belluno & $29.41 \%$ & $5.88 \%$ & $11.53 \%$ \\
\hline 66 & Macerata & $29.27 \%$ & $11.73 \%$ & $18.79 \%$ \\
\hline 67 & Treviso & $28.79 \%$ & $5.95 \%$ & $9.82 \%$ \\
\hline 68 & Palermo & $23.04 \%$ & $4.41 \%$ & $8.22 \%$ \\
\hline
\end{tabular}

Source: Created by the authors.

TABLE 3

Performance in terms of effectiveness for municipalities that do not directly manage nursery school services

\begin{tabular}{|c|c|c|c|c|c|}
\hline \multirow[b]{2}{*}{$N}$. & \multirow{2}{*}{$\begin{array}{c}\text { Main municipality } \\
\text { of province }\end{array}$} & \multirow{2}{*}{$\begin{array}{c}\text { Management } \\
\text { type }\end{array}$} & \multirow{2}{*}{$\frac{\text { Satisfied requests }}{\text { Received requests }}$} & \multirow{2}{*}{$\frac{\text { Available positions }}{\text { Potential users }}$} & \multirow{2}{*}{$\frac{\text { Received requests }}{\text { Potential users }}$} \\
\hline & & & & & \\
\hline 1 & Aosta & 9 & $100.00 \%$ & $16.99 \%$ & $14.38 \%$ \\
\hline 2 & Tempio Pausania & 9 & $100.00 \%$ & $15.38 \%$ & $10.71 \%$ \\
\hline 3 & Lanusei & 9 & $100.00 \%$ & $17.02 \%$ & $17.02 \%$ \\
\hline 4 & Modena & 9 & $94.24 \%$ & $31.70 \%$ & $44.00 \%$ \\
\hline 5 & Parma & 9 & $93.12 \%$ & $35.37 \%$ & $37.98 \%$ \\
\hline 6 & Bergamo & 9 & $83.33 \%$ & $17.38 \%$ & $21.65 \%$ \\
\hline 7 & Villacidro & 5 & $71.09 \%$ & $13.76 \%$ & $33.86 \%$ \\
\hline 8 & Torino & 9 & $68.76 \%$ & $17.65 \%$ & $24.72 \%$ \\
\hline 9 & Ravenna & 9 & $66.34 \%$ & $18.86 \%$ & $30.79 \%$ \\
\hline 10 & Savona & 9 & $66.24 \%$ & $17.97 \%$ & $16.82 \%$ \\
\hline \multirow[t]{2}{*}{11} & Brescia & 9 & $64.75 \%$ & $11.22 \%$ & $15.15 \%$ \\
\hline & Average & - & $59.25 \%$ & $3.31 \%$ & $4.41 \%$ \\
\hline 12 & Rieti & 9 & $55.20 \%$ & $12.55 \%$ & $22.73 \%$ \\
\hline 13 & Trieste & 9 & $54.88 \%$ & $18.15 \%$ & $24.73 \%$ \\
\hline 14 & Cuneo & 9 & $43.20 \%$ & $13.00 \%$ & $12.27 \%$ \\
\hline 15 & Sassari & 9 & $42.02 \%$ & $10.38 \%$ & $13.36 \%$ \\
\hline 16 & Siracusa & 5 & $39.69 \%$ & $10.31 \%$ & $25.98 \%$ \\
\hline 17 & Lucca & 9 & $8.01 \%$ & $10.48 \%$ & $14.65 \%$ \\
\hline
\end{tabular}

Source: Created by the authors.

of staff, the ratio between nursery users and educators is particularly interesting. Here we note that only a part of total staff is made up of educators. In fact, very often the number of children per educator is double - sometimes even triple (Foggia) - the result we would obtain if considering the total number of operators.

Quality aspects illustrated in Table 7 show dimensions of directly managed nurseries to be substantially the same as those with "other forms of management." But data for the number of children per educator show a higher level than that registered for directly managed structures. On this point, we note that the figure for Lucca is highly anomalous and the municipality, when compiling the return, probably only considered its own employees.

Therefore, the results support $H 3$, according to which nursery schools with externalized services have lower levels of quality than those managing services themselves.

Direct management, in comparison with externalization, shows overall performance that is better in terms of effectiveness, cost saving, and quality of the service ulterior proof that, where there is greater political awareness and the service is directly run, better overall performance results. At the same time, according to our research, external management brings no positive element to the overall management of authorities but rather brings lower quality 
TABLE 4

Performance in terms of cost saving by municipalities that directly manage nursery school services

\begin{tabular}{|c|c|c|c|c|}
\hline \multirow[b]{2}{*}{$N}$. & \multirow{2}{*}{$\begin{array}{c}\text { Main municipality } \\
\text { of province }\end{array}$} & Total cost & \multirow{2}{*}{$\frac{\text { Total revenue }}{\text { Attendances }}$} & \multirow{2}{*}{$\frac{\text { Total revenuc }}{\text { Total cost }}$} \\
\hline & & Attendances & & \\
\hline 1 & Crotone & $€ 1,197.38$ & $€ 1,061.75$ & 0.887 \\
\hline 2 & Cosenza & $€ 1,766.36$ & $€ 658.78$ & 0.373 \\
\hline 3 & Macerata & $€ 3,130.80$ & $€ 4.233,92$ & 1.352 \\
\hline 4 & Viterbo & $€ 3,136.86$ & $€ 3,155.10$ & 1.006 \\
\hline 5 & Napoli & $€ 3,710.37$ & $€ \quad 337.50$ & 0.091 \\
\hline 6 & Ancona & $€ 3,716.96$ & $€ 763.89$ & 0.206 \\
\hline 7 & Sondrio & $€ 3,956.07$ & $€ 3,335.24$ & 0.843 \\
\hline 8 & Campobasso & $€ 4,119.15$ & $€ 1,186.97$ & 0.288 \\
\hline 9 & Pescara & $€ 4,132.93$ & $€ 1,367.19$ & 0.331 \\
\hline 10 & Latina & $€ 4,138.55$ & $€ 3,184.69$ & 0.770 \\
\hline 11 & Rimini & $€ 4,285.66$ & $€ 1,481.10$ & 0.346 \\
\hline 12 & La Spezia & $€ 4,324.06$ & $€ 1,504.20$ & 0.348 \\
\hline 13 & Chieti & $€ 4,488.26$ & $€ 1,324.53$ & 0.295 \\
\hline 14 & Novara & $€ 4,801.09$ & $€ 2,698.60$ & 0.562 \\
\hline 15 & Arezzo & $€ 4,926.53$ & $€ 2,155.84$ & 0.438 \\
\hline 16 & Teramo & $€ 4,941.52$ & $€ 1,596.38$ & 0.323 \\
\hline 17 & Trapani & $€ 5,093.60$ & $€ \quad 412.50$ & 0.081 \\
\hline 18 & Belluno & $€ 5,145.97$ & $€ 2,544.69$ & 0.495 \\
\hline 19 & Lodi & $€ 5,295.14$ & $€ 2,971.90$ & 0.561 \\
\hline 20 & Forlì & $€ 5,371.18$ & $€ 1,515.20$ & 0.282 \\
\hline 21 & Udine & $€ 5,396.78$ & $€ 1,110.59$ & 0.206 \\
\hline 22 & Perugia & $€ 5,578.42$ & $€ 2,762.45$ & 0.495 \\
\hline 23 & Terni & $€ 5,735.36$ & $€ 1,601.77$ & 0.279 \\
\hline 24 & Ragusa & $€ 5,775.22$ & $€ 1,938.41$ & 0.336 \\
\hline 25 & Palermo & $€ 5,993.43$ & $€ \quad 546.16$ & 0.091 \\
\hline 26 & Bologna & $€ 5,994.76$ & $€ 1,446.86$ & 0.241 \\
\hline 27 & Siena & $€ 5,997.45$ & $€ 5,337.24$ & 0.890 \\
\hline 28 & Vicenza & $€ 6,137.01$ & $€ 2,369.43$ & 0.386 \\
\hline 29 & Alessandria & $€ 6,193.78$ & $€ 1,223.01$ & 0.197 \\
\hline 30 & Rovigo & $€ 6,217.48$ & $€ 1,699.18$ & 0.273 \\
\hline 31 & Mantova & $€ 6,870.10$ & $€ 2,791.92$ & 0.406 \\
\hline 32 & Pistoia & $€ 6,928.75$ & $€ 2,325.51$ & 0.336 \\
\hline 33 & Carbonia & $€ 6,946.45$ & $€ 4,764.66$ & 0.686 \\
\hline 34 & Milano & $€ 7,087.75$ & $€ 2,013.02$ & 0.284 \\
\hline 35 & Livorno & $€ 7,099.87$ & $€ 2,202.92$ & 0310 \\
\hline 36 & Salerno & $€ 7,191.16$ & $€ 1,509.30$ & 0.210 \\
\hline \multirow[t]{2}{*}{37} & Cagliari & $€ 7,368.65$ & $€ 1,225.05$ & 0.166 \\
\hline & Average & $€ 7,516.02$ & $€ 1,332.65$ & 0.177 \\
\hline 38 & Verbania & $€ 7,943.74$ & $€ 2,652.34$ & 0.334 \\
\hline 39 & Massa & $€ 7,976.35$ & $€ 1,461.63$ & 0.183 \\
\hline 40 & Cremona & $€ 7,978.86$ & $€ 1,636.04$ & 0.205 \\
\hline 41 & Pesaro & $€ 8,113.71$ & $€ 1,937.93$ & 0.239 \\
\hline 42 & Piacenza & $€ 8,114.84$ & $€ 2,210.46$ & 0.272 \\
\hline 43 & Genova & $€ 8,227.82$ & $€ 757.70$ & 0.092 \\
\hline 44 & Roma & $€ 8,377.85$ & $€ \quad 570.29$ & 0.068 \\
\hline 45 & Catania & $€ 8,533.00$ & $€ 1,124.25$ & 0.132 \\
\hline 46 & Vercelli & $€ 8,580.40$ & $€ 2,499.27$ & 0.291 \\
\hline 47 & Foggia & $€ 8,582.10$ & $€ \quad 850.00$ & 0.099 \\
\hline 48 & Lecco & $€ 8,660.42$ & $€ 7,700.73$ & 0.889 \\
\hline 49 & Asti & $€ 9,243.69$ & $€ 3,778.28$ & 0.409 \\
\hline 50 & Imperia & $€ 9,245.78$ & $€ 1,551.03$ & 0.168 \\
\hline 51 & Como & $€ 9,458.86$ & $€ 1,306.51$ & 0.138 \\
\hline 52 & Pisa & $€ 9,481.99$ & $€ 1,611.26$ & 0.170 \\
\hline 53 & Pavia & $€ 9,803.38$ & $€ 2,073.05$ & 0.211 \\
\hline 54 & Biella & $€ \quad 9,911.95$ & $€ 1,488.11$ & 0.150 \\
\hline 55 & Ascoli Piceno & $€ 10,010.44$ & $€ 2,049.23$ & 0.205 \\
\hline
\end{tabular}

(Continued)
TABLE 4

(Continued)

\begin{tabular}{|c|c|c|c|c|}
\hline \multirow[b]{2}{*}{$N$} & \multirow{2}{*}{$\begin{array}{l}\text { Main municipality } \\
\text { of province }\end{array}$} & \multirow{2}{*}{$\frac{\text { Total cost }}{\text { Attendances }}$} & \multirow{2}{*}{$\frac{\text { Total revenue }}{\text { Attendances }}$} & \multirow{2}{*}{$\frac{\text { Total revenue }}{\text { Total cost }}$} \\
\hline & & & & \\
\hline 56 & Verona & $€ 10,313.22$ & $€ 3,389.87$ & 0.329 \\
\hline 57 & Frosinone & $€ 10,526.47$ & $€ 1,647.09$ & 0.156 \\
\hline 58 & Firenze & $€ 10,533.82$ & $€ 1,413.08$ & 0.134 \\
\hline 59 & Treviso & $€ 10,931.20$ & $€ 1,779.29$ & 0.163 \\
\hline 60 & Padova & $€ 10,996.38$ & $€ 2,451.04$ & 0.223 \\
\hline 61 & Enna & $€ 11,366.76$ & $€ 1,005.02$ & 0.088 \\
\hline 62 & Agrigento & $€ 12,182.51$ & $€ \quad 100.00$ & 0.008 \\
\hline 63 & Varese & $€ 12,187.81$ & $€ 3,066.01$ & 0.252 \\
\hline 64 & Trento & $€ 12,345.88$ & $€ 2,222.19$ & 0.180 \\
\hline 65 & Avellino & $€ 13,390.96$ & $€ 1,786.77$ & 0.133 \\
\hline 66 & Prato & $€ 14,621.36$ & $€ 2,879.19$ & 0.197 \\
\hline 67 & Pordenone & $€ 15,988.94$ & $€ 3,149.13$ & 0.197 \\
\hline 68 & Venezia & $€ 18,426.60$ & $€ 1,717.19$ & 0.093 \\
\hline
\end{tabular}

Source. Created by the authors.

services at higher costs. However, the small number of provincial capitals who have chosen to outsource the service might lead to misleading conclusions.

As far as direct management of the service is concerned, we verified the degree of association between the three aspects studied, taken in pairs, using the Pearson's correlation coefficient calculated for the main indicator identified for each aspect. The decision to carry out this analysis just for directly managed services was due to the small number of municipalities using different forms of management. The coefficient always assumes values close to zero so, at least from a purely statistical viewpoint, there is no correlation among the aspects examined (Table 8). The fact that there is neither a positive nor negative correlation among the aspects examined suggests to us that there is no careful monitoring of results regarding the supply and distribution of the directly managed service. Even although the service is, as already frequently mentioned, of strategic economic and social importance, no awareness on the part of authorities was noted in monitoring results achieved.

\section{CONCLUSIONS}

As past research has repeatedly emphasized, the complexities of supplying nursery school services require multidimensional systems of measurement to evaluate performance. For example, Dunleavy et al. (2006) assume a connection among NPM, growing societal complexity, declining trust in bureaucracy, and the representative democracy. There is a great variety in implementation of NPM. As stated by De Vries (2010), "this is explained by the characteristics of the various countries, distinctive political regimes and organizational and institutional cultures and Italian nursery schools are an example of this complexity." Considering the complexity of the management of nursery schools, the 
TABLE 5

Performance in terms of cost saving for municipalities that do not directly manage nursery school services

\begin{tabular}{rlccccc}
\hline & Main municipality & & Total cost & & Total revenue & Total revenue \\
$N$. & of province & Management type & Attendances & & Attendances & Total cost \\
\hline 1 & Parma & 9 & $€ 3,436.60$ & $€ 2,030.54$ & 0.591 \\
2 & Cuneo & 9 & $€ 3,795.23$ & $€ 3,201.32$ & 0.844 \\
3 & Savona & 9 & $€ 4,866.98$ & $€ 1 ., 633.05$ & 0.336 \\
4 & Torino & 9 & $€ 5,478.57$ & $€ 2,795.93$ & 0.510 \\
5 & Lanusei & 9 & $€ 5,528.25$ & $€ 6,083.33$ & 1.100 \\
6 & Villacidro & 5 & $€ 6,346.15$ & $€ 1,346.15$ & 0.212 \\
7 & Siracusa & 5 & $€ 6,970.69$ & $€ 1,858.04$ & 0.267 \\
8 & Tempio Pausania & 9 & $€ 7,318.00$ & $€ 7,316.21$ & 1.000 \\
9 & Ravenna & 9 & $€ 7,524.88$ & $€ 1,268.47$ & 0.169 \\
10 & Modena & 9 & $€ 7,568.76$ & $€ 1,307.76$ & 0.173 \\
& Average & - & $€ 8,612.83$ & $€ 1,407.02$ & 0.163 \\
11 & Lucca & 9 & $€ 8,198.19$ & $€ 1,925.90$ & 0.235 \\
12 & Bergamo & 9 & $€ 10,120.33$ & $€ 1,802.71$ & 0.178 \\
13 & Sassari & 9 & $€ 11,554.08$ & $€ 876.08$ & 0.076 \\
14 & Trieste & 9 & $€ 12,678.17$ & $€ 1,664.65$ & 0.131 \\
15 & Brescia & 9 & $€ 15,266.47$ & $€ 2,365.59$ & 0.155 \\
16 & Rieti & 9 & $€ 16,004.85$ & $€ 4,059.09$ & 0.254 \\
17 & Aosta & 9 & $€ 16,374.23$ & $€ 968.62$ & 0.059 \\
\hline
\end{tabular}

Source: Created by the authors.

multi-dimensional analysis has enabled us to evaluate their performance: data contained in final accounts have allowed us to measure the multi-dimensional aspects of the nursery school service supplied by Italian municipalities, by means of drafting "charts" organized by those performance indicators held to be significant - effectiveness, cost saving and quality.

Regarding overall performance, the distinction between direct management and outsourcing has not brought out significant differences in terms of effectiveness and cost saving, even if, in contrast with the first two hypotheses, the direct management solution is better than the externalized one. Moreover, by contrast, as previous research showed, quality levels for externalized services are on average lower than for directly managed services. Further research developments are necessary in order to confirm or not the results by implementing the set indicators and by utilizing other methods of performance measurement. quantitative and analysis.

Research results demonstrate the need for early childcare services to be orchestrated at national level as we found extreme variations in effectiveness, cost saving, and quality aspects, with values far from the average. These results confirm the fragmentary nursery school system in Italy, and, indirectly the need for a common quality standard for nursery schools, which was raised at European level (Eurydice Report, 2009; Ruggiero, 2010).

If we consider that the only business-economic standard data available to assess performance of nursery school system in Italy are collected in the final accounts of the Ministry or Interior website, it is evident that more efforts are necessary to define data collection, measurement, and benchmarking systems in Italian municipalities and other European settings (NESSE, 2009, p. 63). Moreover, the results highlight the need to improve the nursery school service both in terms of quantity - to reach 33 percent coverage and quality. For the latter aspect, problems are greater due to the lack of a European quality definition. If we consider the principal quality aspects of the service in member countries, there are significant differences connected with forms of management, minimum training for operators, user age, and numerical ratio of operators to children (European Commission, 2008c, p. 10). The same differences are found in Italy on a regional level. Take, for example, the extreme variations in number of children per operator/educator and in the average capacity of structures laid down by regional laws.

Unlike the results of previous research into non-Italian situations, for directly managed services we did not find a positive correlation among the variables examined. In the case of Italy, this lack of correlation may be connected with low awareness concerning measurement of the phenomenon in economic or business terms. The lack of a common monitoring system for strategic aspects of the service depends on the fact that reporting these data in final accounts are considered merely as a bureaucratic duty, rather than as an opportunity to reflect.

Moreover, we believe that issues regarding the availability of childcare structures can in no way be separated from those regarding costs (European Commission, 2008c). The extreme variations found in unit costs, together with their importance within municipal budgets, merit further study in order to understand whether low unit costs are the result of 
TABLE 6

Performance in terms of quality by municipalities that directly manage nursery school services

\begin{tabular}{|c|c|c|c|c|}
\hline \multirow[b]{2}{*}{$N$} & \multirow{2}{*}{$\begin{array}{l}\text { Main municipality } \\
\text { of province }\end{array}$} & \multirow{2}{*}{$\frac{N . \text { available positions }}{N . \text { of nursery schools }}$} & \multirow{2}{*}{$\frac{N . \text { attendance }}{\text { Total operators }}$} & \multirow{2}{*}{$\frac{\text { N. attendance }}{\text { Total educators }}$} \\
\hline & & & & \\
\hline 1 & Macerata & 25,600 & 7 & 14 \\
\hline 2 & Belluno & 26,000 & 5 & 9 \\
\hline 3 & La Spezia & 27,563 & 6 & 8 \\
\hline 4 & Cagliari & 27,895 & 3 & 7 \\
\hline 5 & Udine & 29,000 & 5 & 7 \\
\hline 6 & Pescara & 30,000 & 4 & 5 \\
\hline 7 & Ragusa & 30,200 & 3 & 4 \\
\hline 8 & Frosinone & 31,600 & 3 & 4 \\
\hline 9 & Crotone & 32,000 & 2 & 5 \\
\hline 10 & Venezia & 32,222 & 2 & 4 \\
\hline 11 & Piacenza & 33,050 & 6 & 9 \\
\hline 12 & Ancona & 33,563 & 10 & 11 \\
\hline 13 & Arezzo & 33,857 & 4 & 6 \\
\hline 14 & Terni & 35,000 & 3 & 4 \\
\hline 15 & Livorno & 35,500 & 5 & 6 \\
\hline 16 & Chieti & 36,000 & 2 & 5 \\
\hline 17 & Pisa & 36,056 & 4 & 8 \\
\hline 18 & Firenze & 36,558 & 5 & 8 \\
\hline 19 & Pesaro & 38,214 & 4 & 5 \\
\hline 20 & Napoli & 38,257 & 3 & 5 \\
\hline 21 & Alessandria & 38,667 & 3 & 6 \\
\hline 22 & Vercelli & 39,000 & 6 & 10 \\
\hline 23 & Palermo & 39,217 & 2 & 4 \\
\hline 24 & Siena & 39,222 & 4 & 6 \\
\hline 25 & Enna & 40,000 & 2 & 3 \\
\hline 26 & Bologna & 40,538 & 4 & 6 \\
\hline 27 & Rovigo & 41,333 & 6 & 7 \\
\hline 28 & Trento & 41,864 & 6 & 9 \\
\hline 29 & Viterbo & 42,143 & 6 & 7 \\
\hline 30 & Prato & 42,333 & 3 & 5 \\
\hline 31 & Cosenza & 42,500 & 2 & 3 \\
\hline 32 & Massa & 42,600 & 4 & 4 \\
\hline 33 & Latina & 42,833 & 5 & 6 \\
\hline 34 & Catania & 43,333 & 2 & 3 \\
\hline 35 & Genova & 44,121 & 2 & 3 \\
\hline 36 & Ascoli Piceno & 44,333 & 2 & 6 \\
\hline \multirow[t]{2}{*}{37} & Teramo & 45,167 & 3 & 5 \\
\hline & Average & 46,224 & 4 & 6 \\
\hline 38 & Pistoia & 48,000 & 6 & 9 \\
\hline 39 & Avellino & 48,000 & 3 & 4 \\
\hline 40 & Milano & 48,730 & 6 & 8 \\
\hline 41 & Pordenone & 49,000 & 2 & 4 \\
\hline 42 & Trapani & 49,250 & 3 & 5 \\
\hline 43 & Imperia & 49,333 & 3 & 4 \\
\hline 44 & Perugia & 49,357 & 4 & 4 \\
\hline 45 & Rimini & 49,364 & 6 & 8 \\
\hline 46 & Pavia & 49,875 & 5 & 6 \\
\hline 47 & Biella & 50,000 & 4 & 6 \\
\hline 48 & Agrigento & 50,000 & 3 & 4 \\
\hline 49 & Padova & 50,600 & 3 & 5 \\
\hline 50 & Asti & 51,000 & 4 & 6 \\
\hline 51 & Varese & 51,333 & 3 & 4 \\
\hline 52 & Como & 54,222 & 4 & 7 \\
\hline 53 & Mantova & 54,250 & 2 & 4 \\
\hline 54 & Verona & 54,708 & 3 & 4 \\
\hline 55 & Carbonia & 56,000 & 4 & 6 \\
\hline 56 & Lecco & 60,000 & 4 & 5 \\
\hline
\end{tabular}


TABLE 6

(Continued)

\begin{tabular}{|c|c|c|c|c|}
\hline \multirow[b]{2}{*}{$N$. } & \multirow{2}{*}{$\begin{array}{c}\text { Main municipality } \\
\text { of province }\end{array}$} & \multirow{2}{*}{$\frac{\text { N. available positions }}{N . \text { of nursery schools }}$} & \multirow{2}{*}{$\frac{N . \text { attendance }}{\text { Total operators }}$} & \multirow{2}{*}{$\frac{\text { N. attendance }}{\text { Total educators }}$} \\
\hline & & & & \\
\hline 57 & Treviso & 60,000 & 4 & 7 \\
\hline 58 & Campobasso & 60,000 & 5 & 6 \\
\hline 59 & Foggia & 60,000 & 3 & 10 \\
\hline 60 & Forlì & 60,692 & 6 & 11 \\
\hline 61 & Vicenza & 61,091 & 5 & 6 \\
\hline 62 & Roma & 61,615 & 3 & 7 \\
\hline 63 & Cremona & 62,500 & 8 & 12 \\
\hline 64 & Novara & 66,778 & 4 & 7 \\
\hline 65 & Lodi & 67,000 & 4 & 6 \\
\hline 66 & Sondrio & 72,000 & 4 & 6 \\
\hline 67 & Verbania & 74,000 & 5 & 7 \\
\hline 68 & Salerno & 94,500 & 5 & 11 \\
\hline
\end{tabular}

Source: Created by the authors.

TABLE 7

Performance in terms of quality for municipalities that do not directly manage nursery school services

\begin{tabular}{|c|c|c|c|c|c|}
\hline \multirow[b]{2}{*}{$N$} & \multirow{2}{*}{$\begin{array}{c}\text { Main municipality } \\
\text { of province }\end{array}$} & \multirow[b]{2}{*}{ Management type } & \multirow{2}{*}{$\frac{N . \text { available positions }}{N . \text { of nursery schools }}$} & \multirow{2}{*}{$\frac{\text { N. attendance }}{\text { Total operators }}$} & \multirow{2}{*}{$\frac{\text { N. attendance }}{\text { Total educators }}$} \\
\hline & & & & & \\
\hline 1 & Lanusei & 9 & 24,000 & 4 & 6 \\
\hline 2 & Brescia & 9 & 33,611 & 3 & 4 \\
\hline 3 & Modena & 9 & 36,409 & 6 & 9 \\
\hline 4 & Aosta & 9 & 39,000 & 3 & 4 \\
\hline 5 & Bergamo & 9 & 40,769 & 5 & 6 \\
\hline 6 & Ravenna & 9 & 40,850 & 11 & 11 \\
\hline 7 & Savona & 9 & 41,667 & 5 & 6 \\
\hline 8 & Parma & - & 44,744 & 42 & 11 \\
\hline 9 & Sassari & 9 & 47,286 & 14 & 37 \\
\hline \multirow[t]{2}{*}{10} & Trieste & 9 & 47,611 & 3 & 4 \\
\hline & Average & - & 47,938 & 6 & 10 \\
\hline 11 & Lucca & 9 & 48,200 & 60 & 241 \\
\hline 12 & Siracusa & 5 & 50,857 & 4 & 6 \\
\hline 13 & Villacidro & 5 & 52,000 & 4 & 6 \\
\hline 14 & Tempio Pausania & 9 & 56,000 & 3 & 6 \\
\hline 15 & Torino & 9 & 56,920 & 4 & 6 \\
\hline 16 & Cuneo & 9 & 59,667 & 9 & 14 \\
\hline 17 & Rieti & 9 & 69,000 & 2 & 3 \\
\hline
\end{tabular}

Source: Created by the authors.

TABLE 8

Pearson's correlation coefficient

\begin{tabular}{lc}
\hline & $\begin{array}{c}\text { Pearson's correlation } \\
\text { coefficient }\end{array}$ \\
\hline Cost saving and quality & 0.0879 \\
Effectiveness and cost saving & 0.0907 \\
Quality and effectiveness & 0.0915 \\
\hline
\end{tabular}

Source: Created by the authors.

careful management and to be considered as best practices, or rather of quality decisions that are as a rule aimed low (Gori \& Fissi, 2010).
Considering the service's strategic importance both for the economic development of countries and for associated social aspects, our investigation shows the advisability of keeping it under public control, at least for larger local authorities, and of avoiding outsourcing policies that do not lead to improved economic performance but which, in the majority of cases, compromise quality aspects (Menchini, 2010). Outsourcing policies should be carried out only after a uniform overview is outlined and shared at European level, with standards to be respected by nursery school services and control and, above all, corrective mechanisms to be used by local authorities on the performance of external organizations. 
The value of our research results is limited by the fact that they refer to only one year, 2008. A further development might therefore be to analyze several consecutive years in order to identify relative trends. In the future, it might be useful to broaden research to include smaller municipalities in order to verify whether, in such cases, the use of specialized external organizations results in improved performance (Hasan, 2007; Van Slyke, 2003).

Lastly, as observed when analyzing statistics, the lack of territorial subdivision of performance data is a limit but, at the same time, an opportunity for further study in the future. In fact it would be interesting to verify if average performance levels vary depending on the different territorial zones identified by the Italian National Institute of Statistics (Istat, 2010, p. 3). ${ }^{2}$

\section{REFERENCES}

Afonso, A., \& Aubyn, M. (2005). Non-parametric approaches to education and health efficiency in OECD countries. Journal of Applied Economics, $8(2), 227-246$.

Afonso, A., Schuknecht, L., \& Tanzi, V. (2005). Public sector efficiency: An international comparison. Public Choice, 123(3/4), 321.

Afonso, A., Schuknecht, L., \& Tanzi, V. (2006). Public Sector Efficiency: Evidence for New EU Member States and Emerging Markets. European Central Bank, Working Paper No. 581.

Amirkhanyan, A. A. (2010). Monitoring across sectors: Examining the effect of non-profit and for-profit contractor ownership on performance monitoring in state and local contracts. Public Administration Review, 70(5), 742-755.

Ancarani, A., \& Capaldo, G. (2001). Management of standardized public services: A comprehensive approach to quality assessment. Managing Service Quality, I/(5), 331-341.

Andrews, R., \& Entwistle, T. (2010). Does cross-sectoral partnership deliver? An empirical exploration of public service effectiveness, efficiency, and equity. Journal of Public Administration Research and Theory, 20(3), 679-701.

Angroff, R., \& McGuire, M. (2003). Collaborative public management: New strategies for local governments. Washington, DC: Georgetown University Press.

Audit Commission. (2001). Local authority performance indicators in England and Wales. London: HMSO.

Audit Commission. (2003). Comprehensive performance assessment. London: Audit Commission.

Barlow, J., \& Rober, M. (1996). Steering not rowing: Coordination and control in the management of public services. International Journal of Public Management, 9(5-6), 73-89.

Bel, G., \& Warner, M. (2008). Does privatization of solid waste and water services reduce costs? A review of empirical studies. Resources, Conservation and Recycling, 52(12), 1337-1348.

Bernacchi, E. (2010). Barcelona targets: Difficulties fond by states and national expectations over the identification of qualitative standards by EU. In Istituto degli Innocenti (Eds.), Early childhood education and

${ }^{2}$ Istat divides the regions and their local authorities into five geographical areas: Northwest (Piemonte, Liguria, Lombardia, Valle d'Aosta); Northeast (Trentino Alto Adige, Veneto, Friuli Venezia Giulia, Emilia); Centre (Toscana, Umbria, Marche, Lazio); South (Abruzzo, Molise, Campania, Puglia, Basilicata, Calabria); Islands (Sicilia, Sardegna). care services in the European Union countries. Florence: Istituto degli Innocenti.

Bird, S., Coz, D., Farwell, V., Goldstein, H., Kolt, T., \& Smith, P. (2005). Performance indicators: Good, bad, and ugly Journal of the Royal Statistical Society: Series A (Statistics in Society), 168(1), 1-27.

Bloomfield, P. (2006). The challenging business of long-term public-private partnerships. Public Administration Review, 66(3), 400-411.

Boaz, A., \& Nutley, S. (2003). Evidence-Based management and learning for public service improvement. In T. Bovaird and E. Loffler (Eds.), Public management and governance. London: Routledge.

Boland, T., \& Flower, A. (2000). A systems perspective of performance management in public sector organizations. The International Journal of Public Sector Management, 13(5), 417-446.

Bovaird, T., \& Loeffler, E. (2003). Evaluating the quality of public governance: Indicators, models and methodologies. International Review of Administrative Sciences, 69(3), 313-328.

Boyne, G. A. (1998). Bureaucratic theory meets reality: Public choice and service contracting in U.S. local government. Public Administration Review, 58(6), 474-484.

Boyne, G. A. (2002). Concepts and indicators of local authority performance: An evaluation of the statutory frameworks in England and Wales. Public Money \& Management, 22(1), 17-24.

Boyne, G. A. (2003). Sources of public service improvement: A critical review and research agenda. Journal of Public Administration Research and Theory, 13(3), 367-394.

Boyne, G. A., Meier, K., J., O'Toole, L. J., \& Walker, R.M. (2006). Public service performance: Perspectives on measurement and management. Cambridge: Cambridge University Press.

Bozeman, B. (1987). All organisations are public: Bridging public and private organisational theories. San Francisco: Jossey-Bass.

Brewer, G. A. (2000). Administrative Reform and Organizational Change in the Public Sector. Democracy Project AP 24/2000. Copenhagen, Denmark: University of Copenhagen.

Brown, T. L., Potoski, M., \& Van Slyke, D. M. (2006). Managing public service contracts: Aligning values, institutions, and markets. Public Administration Review, 66(3), 53-67.

Bryson, J. M., Crosby B. C., \& Middleton Stone, M. (2006). The design and implementation of cross-sector collaborations: Propositions from the literature. Public Administration Review, 66(1), 44-55.

Clarke, J. (2004). Dissolving the public realm? The logics and limits of neoliberalism. Journal of Social Policy, 33(1), 27-48.

Commission for Health Improvement. (2003). Rating the NHS. London: Commission for Health Improvement.

Cooper, P. J. (2003). Governing by contract: Challenges and opportunities for public managers. Washington, DC: CQ Press.

Council of Ministers Presidency-Department for European Policies. (2009). Strategia di Lisbona per la Crescita e l'Occupazione. Retrieved December 20, 2011, from http://www.lavoro.gov.it.

Curristine, T., Lonti, Z., \& Joumard, I. (2007). Improving public sector efficiency: Challenges and opportunities. Journal of Budgeting, $7(1)$, $1-41$.

Curry, A., \& Herbert, D. (1998). Continuous improvement in public services. Managing Service Quality, 8(5), 339-349.

Del Boca, D., \& Vuri, D. (2007). The mismatch between employment and childcare in Italy: The impact of rationing. Journal of Population Economics, 20(4), 805-832.

Department for Families. (2007). Piano straordinario dei servizi socioeducativi per la prima infanzia. Rome: Department for Families.

De Vries, J. (2010). Is New Public Management really dead?. Journal on Budgeting 10(1), 1-5.

Dunleavy, P., Margetts, H., Bastow, S., \& Tinkler, J. (2006). New Public Management is dead-long live digital -era governance. Journal of Public Administration Research and Theory, 16(3), 467-494.

Erridge, A., Fee, R., \& Mcllroy, J. (1998). Public sector quality, Political project or legitimate goal?, International Journal of Public Sector Management, 1/(5), 341-353. 
Estache, A., Gonzalez, M. \& Trujillo, L. (2007). Government Expenditures on Education, Health and Infrastructure: A Naïve Look at Levels, Outcomes and Efficiency, City University London, Department of Economics, Discussion Paper Series 07/03.

European Commission. (2007). Proposal for a community Lisbon programme 2008-2010. Brussels: European Commission.

European Commission. (2008a). Memo 08/592. Brussels: European Commission.

European Commission. (2008b). Communication IP/08/1449. Brussels: European Commission.

European Commission. (2008c). Report From The Commission To The European Parliament, The Council, The European Economic And Social Committee And The Committee Of The Regions. Implementation Of The Barcelona Objectives Concerning Childcare Facilities For Pre-SchoolAge Children. Brussels: European Commission.

European Council. (2005). Council Decision of 12 July 2005 on Guidelines for the Employment Policies of the Member States (2005/600/EC), Official Journal of the European Union, 6/8/2005 L. 205/21. Brussels: European Council.

Eurydice Report. (2009). Tackling social and cultural inequalities through early childhood education and care in Europe. Brussels Education: Audiovisual and Culture Executive Agency.

Farrell, J. (1957). The measurement of productive efficiency. Journal of the Royal Statistical Society, 120(3), 253-290.

Ferlie, E. Lynn, L. E., \& Pollitt, C. (2005). The Oxford handbook of public management. Oxford: Oxford University Press.

Ferris, J. M., \& Graddy, E. (1991). Production costs, transaction costs, and local government contractor choice. Economic Inquiry, 29(3), $541-554$.

Forrer, J., Kee, J. E., \& Newcomer, K. E. (2010). Public-Private partnerships and the public accountability question. Public Administration Review, 7O(3), 475-484.

Fraumeni, B. M., Marshall, B. R., \& Brooks, B. B. (2004). Real output measures for the education function of government: A first look at primary and secondary education. Washington, DC: US Bureau of Economic Analysis.

Frederickson, D. G., \& Frederickson, H. G. (2006). Measuring the performance of the hollow state. Washington, DC: Georgetown University Press.

Gibson, T. A. (2010). Primitive accumulation, eminent domain, and the contradictions of neo-liberalism. Cultural Studies, 24(1), 133-160.

Gollust, S. E., \& Jacobson, P. D. (2006). Privatization of public services: Organizational reform efforts in public education and public health. American Journal of Public Health, 96(10), 1733-1739.

Gori, E., \& Fissi, S. (2010). Un'analisi empirica dei servizi indispensabili e di quelli a domanda individuale nei comuni italiani per la determinazione degli standard di costo. Azienda Pubblica, 23(3), 369-389.

Grossi, G., \& Mussari, R. (2008). The effects of outsourcing on performance measurement and reporting: the experience of Italian local governments. Public Budgeting and Finance, 28(1), 22-38.

Gruening, G. (2001). Origin and theoretical basis of New Public Management. International Public Management Journal,/(1), 1-25.

Gulati, R., Nohria, N., \& Zaheer, A. (2000). Strategic networks. Strategic Management Journal, 21, 203-215.

Hansen, M. B., \& Lauridsen, J. (2004). The institutional context of market ideology: A comparative analysis of the values ad perceptions of local government CEOs in 14 OECD countries. Public Administration, 82(2), 491-524.

Hasan, A. (2007). Public policy in early childhood education and care. International Journal of Child Care and Education Policy, /(1), 1-10.

Heeb, R. D., \& Kilburn, R. (2004). The Effects of State Regulations on Childcare Prices and Choices. Rand Labour and Population, Working Paper No 137.

Heinrich, C. J. (2000). Organizational form and performance: An empirical investigation of nonprofit and for-profit job-training service providers. Journal of Policy Analysis and Management, 19(2), 233-261.

Heinrich, C. J. (2002). Outcomes-Based performance management in the public sector: Implication for government accountability and effectiveness. Public Administration Review, 62(6), 712-725.

Hilke, J. (1993). Cost Saving from Privatization: A Compilation of Study Findings, Reason Foundation, How to Guide \#6, March.

Hoffert, S. L., \& Wissoker, D. A. (1992). Price, quality and income in child care choice. Journal of Human Resources 27(1), 70-111.

Hood, C. (1991). A public management for all seasons. Public Administration, 69(1), 3-19.

Hood, C. (1998). The art of the state: Culture, rhetoric, and public management. Oxford: Clarendon Press.

Hoppe, E. I., \& Schmitz, P. (2011). Public-Private Partnerships versus Traditional procurement: An Experimental Investigation.," Social Science Research Network, Discussion Paper No DP 8167.

Istat-National Institute of Statistics. (2010). L'Offerta Comunale di Asili Nido e Altri Servizi Socio-Educativi per la Prima Infanzia. Anno Scolastico 2008/2009. Retrieved December 15, 2011, from http://www. istat.it.

Kelman, S. J. (2002). Strategic contracting management. In J. D. Donahue \&. J. S. Nye Jr. (Eds..), Market-based governance: Supply side, demand side, upside, and downside. Washington, DC: Brookings Institution Press.

Kettel, D. F. (2005). The global public management revolution (2nd Ed..). Washington, DC: Brookings Institution Press.

Landriani, L., \& D'Amore, G. (2009). Outsourcing e performance delle aziende di servizi pubblici locali. Il caso degli Asili Nido. Rome: Quaderni Monografici Rirea.

Lane, J.E. (2000). New Public Management: An introduction. London: Routledge.

Lasker, R. D., Weiss, E. S., \& Miller, R. (2001). Partnership synergy: A practical framework for studying and strengthening the collaborative advantage. Milbank Quarterly, 79(2), 179-205.

Leland, S., \& Smirnova, O. (2009). Reassessing privatization strategies 25 years later: Revisiting Perry and Babitsky's Comparative Performance Study of Urban Bus Transit Services. Public Administration Review, 69(5), 855-867.

Leo, C., \& Enns, J. (2009). Multi-level governance and ideological rigidity: The failure of deep federalism. Canadian Journal of Political Science, 42(1), 93-116.

Levine, D. M., Krehbiel, T. C., \& Berenson, M. L. (2002). Statistica. Milan: Apogeo.

Lewis, B. D., \& Pattinasarany, D. (2009). Determining citizen satisfaction with local public education in Indonesia: The significance of actual service quality and governance conditions. Growth and Change, 4Q(1), 89-115.

Loughlin, J. (2009). The hybrid state: Reconfiguring territorial governance in Western Europe. Perspectives on European Politics and Society, 10(1), 49-66.

Malley, J., \& Fernandez, J. L. (2010). Measuring quality in social care services: Theory and practice. Annals of Public and Cooperative Economics, $87(4), 559-582$.

Mandl, U., Dierx, A., \& Ilzokovitz, F. (2008). The Effectiveness and Efficiency Of Public Spending. European Commission-Economic and Financial Affairs, Economic Papers 301.

Menchini, L. (2010). The ongoing transition of child care in the economically advanced countries. In Istituto degli Innocenti (Eds.), Early childhood education and care services in the European Union countries. Florence: Istituto degli Innocenti.

Mercer, J. L. (1983). Growing opportunities in public service contracting. Harvard Business Review, 6l(2), 178-186.

Mihaiu, D. M., Opreana, A., \& Cristescu, M. P. (2010). Efficiency, effectiveness and performance of the public sector. Romanian Journal of Economic Forecasting, 4, 132-147. 
Ministry for Equal Opportunities. (2007). Piano straordinario di intervento per lo sviluppo del sistema territoriale dei servizi socio-educativi per la prima infanzia. Rome: Ministry for Equal Opportunities.

Ministry for Public Administration and Innovation. (2010). Indagine conoscitiva sugli asili nido nelle pubbliche amministrazioni. Rome: Formez.

Morten Balle, H. (2011). Antecedents of organizational innovation: The diffusion of New Public Management into Danish local government. Public Administration, 89(2), 285-306.

National Family Conference. (2010). Il Piano Straordinario per lo Sviluppo dei Servizi Socio-Educativi per la Prima Infanzia. Sintesi del Monitoraggio, Milan, November 8-10.

NESSE-Network of Experts. (2009). Early Childhood Education and Care. Key lessons from Research for Policy Makers. Retrieved December 15, 2011, from http://www.nesse.fr/nesse/activities/reports/ecec-report-pdf.

OECD. (2007a). Public Spending Efficiency: Institutional Indicators in Primary and Secondary Education. Economic Department Working, Papers No. 380.

OECD. (2007b). Education at a glance 2007. OECD indicators. Paris: OECD.

Osborne, A., \& Gaebler, T. (1992). Reinventing government: How the entrepreneurial spirit is transforming public sector. Reading MA: Addison-Wesley.

Ostroff, C., \& Schmitt, N. (1993). Configurations of organizational effectiveness and efficiency. Academy of Management Journal, 36(6), $1345-1361$.

Plantenga, J., Remery, C., Siegel, M., \& Sementini, L. (2008). Childcare services in 25 European Union member states: The Barcelona targets revisited. Comparative Social Research, 25, 27-53.

Pollitt, C., \& Bouckaert, G. (2004). Public management reform: A comparative analysis. (2nd Ed..). Oxford: Oxford University Press.

Pollitt, C., \& Geert, B. (2000). Public management reform, a comparative analysis. Oxford: Oxford University Press.

Rainey, H. G. (1989). Public Management-Recent research on the political context and managerial roles, structures and behaviours. Journal of Management, 15(2), 229-250.

Reichard, C. (2002). Marketisation of public services in Germany. International Public Management Review, 3(2), 63-79.

Ruggiero, R. (2010). An evaluation of different models of ECEC systems developed at the national level. In Istituto degli Innocenti (Eds.) Early childhood education and care services in the European Union countries. Florence: Istituto degli Innocenti.
Sanderson, I. (1996). Evaluation, learning and effectiveness of public services. International Journal of Public Sector Management, 9(5/6), $90-108$.

Savas, E. S. (2000). Privatization and public-private partnerships. New York: Chatham House Publishers.

Savas, E. S. (2005). Privatization in the city: Successes, failures, lessons. Washington, DC: CQ Press.

Schacter, M. (2002). Not a tool kit practitioner's guide to measuring the performance of public programs. Ottawa, Canada: Institute on Governance.

Siemiatycky, M. (2011). Public-Private partnership networks: Exploring business - government relationships in United Kingdom transportation projects. Economic Geography, 87(3), 309-334.

Tanzi, V., \& Schuknecht, L. (2000). Public spending in the $20^{\text {th }}$ century: A global perspective. Cambridge: Cambridge University Press.

Torres, L., \& Pina, V. (2002). Changes in public services delivery in the EU countries. Public Money and Management, 22(4), 41-48.

Toto, T. (2010). Asili Nido comunali. Dossier a Cura dell'Osservatorio Prezzi \& Tariffe di Cittadinanzattiva. Rome: Cittadinanzaattiva.

Trotta, M., Scarozza, D., Hinna, A., \& Gnan L. (2011). Can information system facilitate the integration of New Public Management and public governance? Evidence from an Italian public organization. Information Polity, 16(1), 23-34.

UNICEF. (2008). The child care transition. Florence: Research Centre Innocenti.

Van Der Steen, I. (1996). Pubblica amministrazione, prestazione di servizi e meccanismi di mercato nei paesi bassi. In Atti del Convegno Cenform, Qualità dei servizi pubblici all'impresa e dei servizi sociali nel contesto Europeo. Rome: Cenform.

Van Slyke, D. M. (2003). The mythology of privatization in contracting for social services. Public Administration Review, 63(3), 277-296.

Vickers, J., \& Wright V. (1988). (Eds..) The politics of privatisation in Western Europe. London: Cass.

Walker, R. M., Brewer, G. A., Boyne, G. A., \& Avellaneda, C. N. (2011). Market orientation and public service performance: New Public Management gone mad? Public Administration Review, 7/(5), 707-717.

Warner, M. E., \& Germa, B. (2008). Competition or monopoly? Comparing privatization of local public services in the U.S. and Spain. Public Administration, 86(3), 723-736.

Wholey J. S., \& Hatry, H. (1992)., "The case for performance monitoring. Public Administration Review, 52(11/12): 604-610.

Zollino, F. (2010). I servizi di cura per la prima infanzia. In Bianco M. M. and Sestito, P. (Eds.), I servizi pubblici locali. Bologna: Il Mulino. 